\title{
The Basic Experience in Chinese Urbanization Since the Reform and Opening-up
}

\author{
JiaoXiaoyun \\ School of Marxism, Hunan Normal University, \\ No. 36, Lushan Street, Yuelu District, Changsha Hunan, China \\ E-mail: jiaoxiaoyun2008@163.com
}

Keywords: Reform and opening-up; urbanization; basic experience

\begin{abstract}
Chinese urbanization has acquired major achievements since the reform and opening-up policy. Under the leadership of Communist Party of China (CPC), basic experience in Chinese urbanization is shown as follows: The strong leadership of CPC is an important safeguard to develop urbanization rapidly; Emancipating people's mind is an inexhaustible motive force to promote urbanization; high-efficient top-level design is the key to promote urbanization; innovative explosion of local governments is the source of vitality for urbanization; constant innovation of system mechanism is a necessary condition to promote sound development of urbanization; simultaneous development of "Four Modernizations" is an objective law of economic development; Using experience of other countries for reference positively is an important condition to achieve success in Chinese urbanization.
\end{abstract}

\section{Introduction}

New-Type Urbanization Planning of the Nation(2014-2020) definitely points that it is necessary to walk a new-type urbanization road with Chinese characteristics of people first, simultaneous Four Modernizations, optimized layout, ecological civilization and cultural inheritance. The new-type urbanization road with Chinese characteristics is the high concision and summary of CPC's practical experience in Chinese urbanization. In a sense, the reason for CPC leading Chinese people to win again and again is because it is good at drawing lessons from the past. With the development of economic society, Chinese urbanization has acquired major achievements since form the reform and opening-up policy. In 2011, urban population in China exceeded rural population for the first time and China started to be transformed into an "urban-oriented" country. The basic experience that CPC leads Chinese people to do urbanization mainly includes 7 aspects as follows:

\section{The strong leadership of CPC is an important safeguard of successful urbanization}

It is impossible to promote urbanization and coordinate with power in various aspects to make progress in socialist cause with Chinese characteristics, if it has no leadership of CPC in such a complicated great power. The promotion of urbanization must insist in the Party's leadership and this is determined by the nature of China and the Party. According to the Constitution and Party Constitution, Chinese affairs must be led by CPC, let alone urbanization. Without the leadership of CPC, Chinese socialism definitely will walk up to a "crooked road" and "evil way", thus our urbanization must go bad. CPC is the stabilizer of Chinese society. Except for common development of industrialization, informatization and agricultural modernization, the promotion of urbanization also needs a stable social environment. This is the necessary condition of urbanization or even the entire national economic development. Deng Xiaoping has emphasized on the importance of stability repeatedly, since from the reform and opening-up policy. The sentence that "maintaining stability is of top priority" is his wise saying. In 1989, Deng Xiaoping pointed that "the overwhelming problem in China is to keep stable. Without stable environment, nothing will be finished and acquired achievements will be lost, either." Jiang Zemin, Hu Jintao and Xi Jinping also explore the relationship among "revolution, development and stability" with varying degrees. 
Before over 100 years of taking power by CPC, China has had all kinds of wars and disasters. Lands fell into disuse and the masses had no means to live. Only in the new China led by CPC, people can live and work in peace and contentment, administer state affairs and manage economic, cultural and social undertakings as their wishes. Only under the stable social environment can we concentrate on constructing and pursue for development with undivided attention. The truth proves that only to insist in the leadership of CPC can we unite with all power to promote constant development of urbanization. Only to stick to the leadership of CPC can we ensure achievements of urbanization are shared by the masses fairly. CPC is the political safeguard to realize national prosperity, national revitalization and people's happiness. As a result, Chinese urbanization must insist in the leadership of CPC.

\section{Emancipating people's mind is an inexhaustible motive force of promoting urbanization}

Before the Third Plenary Session of the $11^{\text {th }}$ Central Committee of CPC, Deng Xiaoping pointed that emancipating people's mind was the primary task of socialist modernization, because it concerned the success or failure of socialist cause. "If we don't break down mental stagnation and don't emancipate cadres and the masses' mind, four modernizations will stand no chance at all." "If a Party, a country and a nation begin with bookishness, have mental stagnation, and spread superstition widely, it is impossible to make progress and vitality just stops, thus the Party and the country will be perished. ${ }^{2 \text { " } X i ~ J i n p i n g ~ r e g a r d s ~ e m a n c i p a t i n g ~ p e o p l e ' s ~ m i n d ~ a s ~ t h e ~ l i v i n g ~ s o u l ~ o f ~}$ Marxism and the fundamental thinking weapon for CPC to "adapt to a new situation, recognize a new thing and complete a new task." The experience in over 30 years of the reform and opening-up policy shows that the degree of emancipating people's mind determines the development degree of our undertakings. The basic experience in over 30 years of the reform and opening-up policy and modernization construction, emancipating people's mind drives the large-scale development of undertakings. After the foundation of new China and before the reform and opening-up policy, the superincumbent economic development model under the urban-rural dual social structure limited urban-rural mobility strictly, but only transferred a few populations from rural areas in the forms of conscription, recruitment and enrollment under the circumstance that towns required for it. Though the implementation of this policy was determined economic conditions at that time, it caused slow development of Chinese urbanization before the reform and opening-up policy objectively. The nation restrained peasants in rural areas through administrative enforcement forcefully, but transferred lots of agricultural and sideline products and agricultural capital to cities for industrial development, resulting in malformation and poverty of rural areas, as well as the imbalance of slow urbanization development and rapid industrialization development. Deng Xiaoping has raised the great discussion on "the truth criterion", since from the Third Plenary Session of the $11^{\text {th }}$ Central Committee of CPC to emancipate people's mind and thus to open the door of the reform and opening-up policy in China. The urbanization of bottom-up processing with the faucet of township enterprises urged Chinese urbanization to make progress in the form of accelerated speed. Afterwards, the introduction of foreign capital and increase of advanced technology and management experience made Chinese urbanization become multi-element driving. This speeded up the progress of Chinese urbanization and shortened the urban-rural gap, the gap between workers and peasants, as well as the gap between manual labor and brainwork gradually. It follows that only to emancipate people's mind and innovate can it provides continuous power for the Chinese urbanization or even the entire national economic development.

\section{High-efficient top-level design is the key to promote urbanization.}

Days after the reform and opening-up policy were the golden age of the most stable Chinese economic society and the greatest development speed and also the important period of developing urbanization rapidly. Except for the late-mover advantages, the reason for sound and rapid development of Chinese urbanization and completion of urbanization progress within 30 years(which might be completed by western countries for more than 100 hundred) lied in the 
high-efficient and correct top-level design(see Table 1). In order to promote urbanization, the nation promoted a series of policies successively. Some of them aimed at the urbanization directly, such as New-Type Urbanization Planning of the Nation(2014-2020) formulated by referring to the $10^{\text {th }}$ five-year plan; some of them guided from the harmonious development of urbanization, such as 16 central "No. 1 documents" looking at "issues of agriculture, farmers and rural areas" and Decision on Development of the Third Industry to promote its development, etc. The official document about urbanization under the national leadership was the Key Specialized Planning of " $10^{\text {th }}$ Five-Year Plan's” urbanization development (2001-2005). The document analyzed the current status and problems of Chinese urbanization, defined the development direction during the period of " $10^{\text {th }}$ Five-Year Plan" and pointed out the direction for the relevant system revolution. This was the first top-level design of constructing Chinese urbanization and was the landmark document with major significance in the history of Chinese urbanization. Afterwards, the reports of the Sixteenth National Congress of CPC, the Seventeenth National Congress of CPC, and the Eighteen National Congress of CPC also had relevant discussion on urbanization. Particularly, the report of the Sixteenth National Congress of CPC proposed the "urbanization road with Chinese characteristics" and brought urbanization into the socialist road with Chinese characteristics, so as to enhance it to the degree of national strategies. The central urbanization's working conference convoked in 2013 conducted the specific deployment on the Chinese urbanization. The conference "analyzed the urbanization situation, promoted guiding though, main tasks, primary principles, and major tasks of urbanization", "discussed the acting point of the current urbanization and came up with the specific deployment of carrying out the process of urbanization." In March 2014, the nation issued the New-Type Urbanization Planning of the Nation(2014-2020). The issuing of the Planning took more than 3 years. It was a corpus of work and contained the collective wisdom of the Party and the nation. The Planning schemed and arranged guiding though, development goals and development paths of new-type urbanization comprehensively. This was the programmatic document of promoting Chinese urbanization. We should run without stopping and go the big figure with a blueprint. In 2015, the Nation issued the Comprehensive Experimental Scheme of the National New-type Urbanization to list national new-type urbanization experimental units of new-type urbanization in 62 cities (towns), including Jiangsu, Anhui and Ningbo, etc., In Feb. 2016, the State Council issued Several Opinions on Developing Deep New-type Urbanization, scheduled citizenization of migrant workers and promotion of urban functions, and aimed at promoting people-oriented urbanization. Afterwards, the CPC and the State Council issued Several Opinions on Further Reinforcing Urban Planning and Construction and sketched a "roadmap" for the development of Chinese characteristic cities. The high-efficient top-level design will be beneficial to from the top-down consensus, so as to point out a direction for urbanization. This will promote the sound and order development of urbanization

Table 1 Main Policies of Impacting Chinese Urbanization since the Reform and Opening-up

\begin{tabular}{|c|c|c|}
\hline Date & National Policies & Influences on Urbanization \\
\hline 1979 & $\begin{array}{l}\text { Decisions of Several Decisions on CPC Accelerating Agricultural } \\
\text { Development }\end{array}$ & $\begin{array}{l}\text { Small town construction promoted to be } \\
\text { development with plans }\end{array}$ \\
\hline $1980 \mathrm{~s}$ & $\begin{array}{l}\text { Stipulations on Solving National Grain Supply for Rural } \\
\text { Relations of Some Technical Cadres Moving to Towns, CPC's } \\
\text { Notification of Rural Work in 1984, Notification of Peasants" } \\
\text { Settlement in Towns, Temporary Stipulations on Management of } \\
\text { Urban Temporary Resident Population, and Notification of } \\
\text { Controlling "Excessive Growth From "Agricultural Population } \\
\text { to Non-Agricultural Population" Strictly, etc. }\end{array}$ & $\begin{array}{l}\text { Loosened the limitation of rural population } \\
\text { mobility gradually, moved rural relations of } \\
\text { technical cadres with some skills to towns, and } \\
\text { settled down, as well as implemented } \\
\text { "temporary Residential Permit, and limited } \\
\text { excessive mobility of rural population. }\end{array}$ \\
\hline 1996 & $\begin{array}{l}\text { Suggestion on National Economy and Social Development's } \\
\text { "Ninth Five-Year Plan" and Vision in } 2010\end{array}$ & $\begin{array}{l}\text { Empl } \\
\text { of La }\end{array}$ \\
\hline 1997-2001 & $\begin{array}{l}\text { Experimental Scheme of Small Towns' Household Registration } \\
\text { System Reform, Some Opinions on Promoting Small Towns' } \\
\text { Household Registration System Reform, Several } \\
\text { Recommendations on Promoting Sound Development of Small } \\
\text { Towns, and Decisions About Major Problems in Agriculture and } \\
\text { Rural Work of CPC, etc. }\end{array}$ & $\begin{array}{l}\text { Reformed household registration system of } \\
\text { small towns, opened the household registration } \\
\text { limitation of small towns comprehensively and } \\
\text { promote population mobility }\end{array}$ \\
\hline 2001 & $\begin{array}{l}\text { Key Specialized Stipulations on “ } 10^{\text {th }} \text { Five-Year Plan” of } \\
\text { Urbanization(2001-2005) }\end{array}$ & $\begin{array}{l}\text { As the first top-level design aiming at } \\
\text { urbanization, defined the development }\end{array}$ \\
\hline
\end{tabular}




\begin{tabular}{|c|c|c|}
\hline & & $\begin{array}{l}\text { direction during the period of " } 10^{\text {th }} \text { Five-Year } \\
\text { Plan", and pointed out the direction of relevant } \\
\text { system reform }\end{array}$ \\
\hline 2008 & $\begin{array}{l}\text { Decision on Several Major Problems of CPC Promoting Rural } \\
\text { Reform Development }\end{array}$ & $\begin{array}{l}\text { Promoted household registration system } \\
\text { reform, broadened settlement conditions of } \\
\text { small and medium-sized cities, and changed } \\
\text { peasants who worked and lived in towns stably } \\
\text { into urban residents }\end{array}$ \\
\hline 2011-2015 & $\begin{array}{l}\text { Notification on Promoting Household Registration System } \\
\text { Reform Positively and Stably in General Office of the State } \\
\text { Council, Opinions on Further Promoting Household Registration } \\
\text { System Reform in the State Council, and Provisional Regulations } \\
\text { of Residence Permit, etc. }\end{array}$ & $\begin{array}{l}\text { Explored household registration system with } \\
\text { hardship, abolished the division of } \\
\text { "agricultural household" and "non-agricultural } \\
\text { household", implemented system of residence } \\
\text { permit and stripped all kinds of welfares } \\
\text { attaching to household }\end{array}$ \\
\hline 2012 & $\begin{array}{l}\text { Development Along the Socialist Road with Chinese } \\
\text { Characteristics in Constancy-Striving for Comprehensive } \\
\text { Construction of a Moderately Prosperous Society }\end{array}$ & $\begin{array}{l}\text { Proposed "new Four Modernizations" and } \\
\text { emphasized on harmonious development of } \\
\text { industrialization, urbanization, informatization } \\
\text { and agricultural modernization }\end{array}$ \\
\hline 2014 & New-Type Urbanization Planning of the Nation(2014-2020) & $\begin{array}{l}\text { Planned and arranged guiding thought, } \\
\text { development goals and development paths of } \\
\text { new-type urbanization comprehensively, and } \\
\text { became the programmatic document of } \\
\text { promoting urbanization in new period }\end{array}$ \\
\hline 2015 & $\begin{array}{l}\text { Comprehensive Experimental Scheme of the National New-type } \\
\text { Urbanization }\end{array}$ & $\begin{array}{l}\text { Listed comprehensive pilot areas of national } \\
\text { new-type urbanization in } 62 \text { cities(towns), } \\
\text { including Jiangsu, Anhui and Ningbo, etc., and } \\
\text { entered into the implementation stage with } \\
\text { people first }\end{array}$ \\
\hline 2016 & $\begin{array}{l}\text { Several Opinions on Further Reinforcing Urban Planning and } \\
\text { Construction }\end{array}$ & $\begin{array}{l}\text { Sketched a roadmap of developing Chinese } \\
\text { characteristic cities and pointed out a direction } \\
\text { of urbanization from the level of urban } \\
\text { planning, urban construction and urban } \\
\text { governance, etc. }\end{array}$ \\
\hline
\end{tabular}

\section{Innovative exploration of local governments is the energy source of urbanization}

China is an agricultural great power with a vast territory, numerous population, complicated geographical environment and humanistic customs. Therefore, the top-level design of the nation only can be a directional pointer, but can't be general panacea with universality. In the promotion process of urbanization, various local governments should promote urbanization explosively in accordance with their geographical position, environmental bearing ability, local features, and custom conditions, etc. In this way, it can avoid from "one side in thousands of cities”, really make cities integrate into the nature, let residents see mountains and rivers and have homesickness. Therefore, innovative exploration of local governments is the energy source of urbanization. Local governments should demonstrate pilots in a small range and promote gradually after summarizing experience. For example, Guangdong took the lead in implementing "integral household" policy positive. Henan took the lead in executing "link between people and land".

The integral household policy means that migrant workers can apply for settlement, after they reach some standards for all checked scores in line with integral rules. This is the effective exploration and attempt on the implementation method of migrant workers' urban settlements on the basis of the current dual household registration management. On the one hand, it relieves the huge expenditure in cities to provide social public services for new households. On the other hand, it can attract sophisticated talents through the policy. This is beneficial to promote the development of local economy. Guangdong started to implement it in 2011. Nowadays, it has been popularized in the whole country. The practice proves that under the current mode of household registration management, integral system is an effective attempt to solve a settlement problem of migrant workers. "Link between people and land" was a beneficial exploration when Henan took the lead in trying to solve the land resource wastes between cities and villages, as well as various areas. The essence of "link between people and land" means that "land develops along with people". In other words, no matter where you are, your own land will follow you. It mainly includes three aspects as follows: First of all, for cities, urban construction land combines with scale of cities absorbing 
agricultural migrants. The number of urban occupation determines the corresponding agricultural migrants. In addition, cities also should be responsible for infrastructures, public services and households of agricultural migrants and realize the human spatial transference driving the optimization of land spatial structure. Secondly, for peasants, it is necessary to reform land expropriation system of rural areas, speed up confirmative circulation of rural land property right, safeguard property earnings of peasants, and solve some basic safeguard problems of employment, medical treatment and social insurance in the future. For peasants who are lack of skills, it is necessary to train them in multiple levels, improve their cultural quality and comprehensive quality, ensure permanent livelihood and let all people enjoy achievements of urbanization. Thirdly, for the urban-rural relation, it is necessary to establish urban-rural land replacement, encourage agricultural migrants to replace urban registered permanent residence, social welfare, and social safeguard with rural contracting responsibility fields, and use the homestead to replace the urban residence. The implementation of this policy solves the land resource waste phenomenon that some agricultural migrants have the residence and the homestead in both cities and rural areas and increases urban construction site and rural residential land and cultivated land effectively.

\section{Simultaneous promotion of four modernizations is the objective law of urbanization}

The report of the Eighteen National Congress of CPC promoted the "new four modernizations" and mutual relation in the new period of Socialist Modernization. "It is necessary to insist in the road of new industrialization, informatization, urbanization and agricultural modernization with Chinese characteristics, promote deep integration between informatization and industrialization and benign interaction between industrialization and urbanization, mutual coordination of urbanization and agricultural modernization, promote synchronous development of industrialization, informatization, urbanization and agricultural modernization. ${ }^{5}$ ” New-type urbanization interacts and promotes the other "three modernizations" mutually. They also have their own internal features and constitute in the inseparable unified entirety of "new four modernizations (Figure 1).

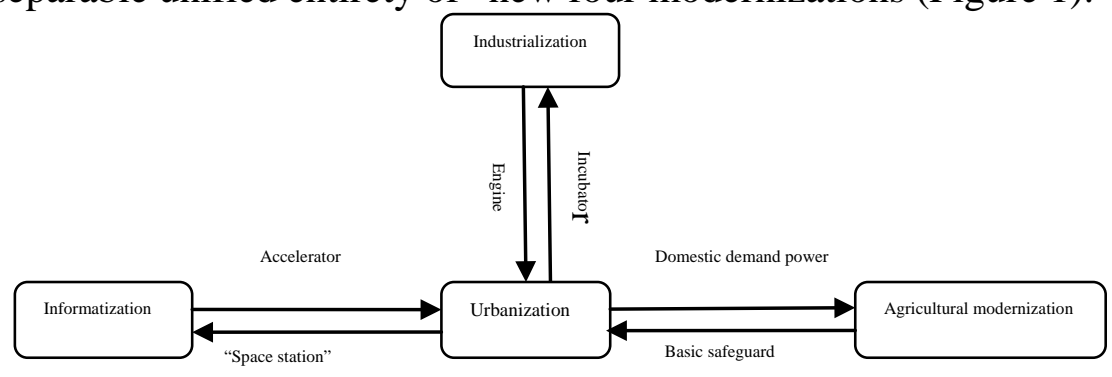

Fig.1 The Relationship between Urbanization and the Other "Three Modernizations"

Urbanization is the incubator of industrialization. Industrialization is the engine of urbanization. The urbanization without industrial supporting is just like a vehicle without the engine. It may be lack of vitality and competitiveness. Industrialization without urbanization is just like the aged who lives in solitude. It may be lack of development space and growth power. On March $5^{\text {th }}, 2013, \mathrm{Li}$ Keqiang who was the vice premier of the State Council, participated in the deliberation of Shandong delegation and emphasized that "the high integration between industrialization and informatization is the important mark of new modernizations. ${ }^{6}$ " The high integration between industrialization and informatization is beneficial to develop the industry, can provide powerful industrial supporting and technical support for urbanization, and is beneficial to develop smart new-type cities and promote the progress of urbanization. Urbanization is the "space station" of informatization and informatization is the accelerator of urbanization. Urbanization provides the regional space and development opportunities for the informatization development, while informatization offers information data and technical support to urbanization. The biggest difficult problem encountered by the current urbanization is to how to configure resources and conduct planning layout of cities. In the rapid development process of urbanization, some phenomena emerge in endlessly, such as occupied high-quality lands, unreasonable urban planning, and serious 
ecological environmental pollution. The innovation of scientific technology and popularity of information technology are effective approach to crack the conflict between resource limitation and demand unlimitedness. Urbanization should pay more attention to quality promotion and connotation development, introduce informatization concept and advanced technology to planning of new-type urbanization, and apply internet of things, mobile internet, e-commerce, e-government affairs and big data, etc., to the urbanization, so as to forge a series of smart cities, information cities and digital cities. The construction of smart cities is good for urban planning. The optimization of urban layout is beneficial to expand overall quality and market competitiveness of agricultural migrants and improve land utilization efficiency and urban economic development. Agricultural modernization is the important foundation and safeguard $\mathrm{f}$ urbanization. Urbanization provides domestic demand power for agricultural modernization. The promotion of mechanized agriculture and application of new technologies in agriculture improve labor productivity of agriculture and produce lots of agricultural residual products. The development of urbanization needs production data and labor force. In this way, lots of agricultural residual products enter into cities with workers. Agricultural population gradually moves to cities as workers and urban constructors, so as to promote the urban formation and development. The urbanization requires for more means of production. In order to produce more means of production on the limited land, it only can depend on the scale operation and realize agricultural modernization. Agricultural modernization requires rural areas to implement land transfer, industrial operation and apply advanced technology. This is good for improving agricultural labor productivity and anti-risk capability, so that we can acquire more supplies of agricultural products on the limited land as much as possible and ensure urban development and basic life demands of urban residents.

\section{Referring to experience in other countries positively is an important condition for our urbanization to succeed.}

Chinese urbanization has been advanced rapidly, since from the reform and opening-up policy. Except for the late-mover advantages and high-efficient top-level design, an important reason is because we are good at absorbing experience and lessons from other countries' urbanization. Every country has its own special national conditions. Thus we can refer to experience from other countries' urbanization, but we can't implement "bringism". Every country only can adjust measures to local conditions and walk their own urbanization road with national characteristics in accordance with their economic development level, political system characteristics, historical cultural accumulation, and geographic position environment, etc.

On the one hand, we should learn and refer to experience of urbanization from high-level and high-quality countries. France has the title of "China in Europe". The entire social development status is extremely similar to China. Therefore, experience of French urbanization has a unique value to China. The main experience of French urbanization means to combine correct leadership of the government and positive participation of peasants, greatly development agricultural occupational education, and improve comprehensive equality of urbanization subjects. Britain insists in the urbanization development road of letting nature take its course. The British urbanization is the natural development process after industrialization and agriculture are developed to some extent. It is a relatively mature development mode. The urbanization of Singapore is promoted under the leadership of the government. The slogan of the government aims to build a green livable city. In the urbanization process, national urban planning plays a vital role. The urbanization modes of these three countries stand for three different types: In France, it is the combination between governmental leadership and peasants' independence. In Britain, the active migration of peasants is the biggest characteristic. The Singapore is the government-oriented model. Though three of them have different forms, they have acquired a great success. They enlighten us that it is necessary to integrate urban planning with relevant laws, realize harmonious development between urban construction and industrial agriculture, and conduct synchronous promotion between industrial supporting and inter-city transportation. On the other hand, we also should learn lessons from excessive urbanization in Latin American countries. By inspecting the development process of 
world urbanization, main driving force of urbanization is the development of industrialization, while urbanization in Latin American countries is mainly driven by foreign trade. They insist in the capital concentrated industry. The urbanization built on the industrial base has larger dependence on foreign trade, but it is lack of local industrial supporting. The urbanization in Latin countries is developed rapidly. "The urban population in Latin American countries occupied 64\%, 71.9\% and $77.7 \%$ of total population in 1980, 1990 and 1997, respectively ${ }^{7}$. Because urbanization in Latin American countries is short of planning and industrial supporting, resulting in lots of slums in their countries. There is a new "edging class" in cities. The excessive urbanization cause generates general deterioration of the nature, society and ecological environment. As a matter of fact, Chinese urbanization was rooted in low-price production elements, instead of industrialization development with feature of technical revolution. This has some similarities with Latin American countries to some extent. Therefore, we should learn a lesson, don't make a sudden and violent attack, and walk on the harmonious development road of new industrialization, informatization, urbanization and agricultural modernization. For China, it should begin with the basic national conditions of low social development level in Chinese economy and primary stage of socialism for a long time, insist in common development of "four modernization, realize the coupling interaction between urbanization and industrialization, deep integration of industrialization and informatization, and harmonious development of urbanization and agricultural modernization, and walk on a new-type smart, green and low-carbon urbanization role, including high scientific contents, less environment pollutions and integrating with sustainable development.

\section{Author}

Jiao Xiaoyun(1980- ), male, School of Marxism, Hunan Normal University, lecturer, ph. D, Mainly engaged in the study of Marxism and Urbanization in China.

\section{References}

[1]. Deng Xiaoping, Literary Selection of Deng Xiaoping (Vol. 3)[M], Beijing, People’s Publishing House, 1993: 284l;

[2]. Deng Xiaoping, Literary Selection of Deng Xiaoping (Vol. 2)[M], Beijing, People’s Publishing House, 1994(version 2): 143;

[3]. The Important Reader of General Secretary of President Xi(Version: 2016)[M], Beijing Learning Publishing House and People’s Publishing house, 2016, 37;

[4]. Working Conference of Central Urbanization Held in Beijing[N], People’s Daily, December $15^{\text {th }}, 2013$ (version 001);

[5]. Important Literature Selections from the Eighteen National Congress of CPC(Volume One)[M], Beijing: Central Party Literature Press, 2014: 16;

[6]. Chen Erhou and Wang Haiying, Urban-Rural Coordinative Development of Promoting New-type Four Modernization Simultaneously[N], People’s Daily, March 6 ${ }^{\text {th }}$, 2013(Version 4);

[7]. Sun Hongzhi, Latin American Urbanization and Its Enlightenment on China[J], Economics of Finance and Trade, 2007(12): 136. 